\title{
Correspondence between phenotype tests of boars and progeny evaluations made on boars and barrows
}

\author{
Elsi Ettala \\ University of Helsinki, Department of Animal Breeding ${ }^{\mathbf{1}}$ )
}

\begin{abstract}
Fifteen boars tested at the experimental station were evaluated on the basis of 120 boars and 120 barrows from their progeny, one boar and one barrow being taken from each of their litters. Compared with the barrows, the boars of the progeny had a higher growth rate $(\mathrm{P}<0.01)$, were meatier $(\mathrm{P}<0.001)$, had less fat $(\mathrm{P}<0.001)$ and were longer $(\mathrm{P}<0.001)$.

Significant phenotypic correlations existed between the ultrasonic fat measurements of the sires and the results of the lean cuts analysis of the most valuable parts of the boar and barrow carcasses $(\mathrm{P}<0.05-\mathrm{P}<0.001)$. The corresponding correlations with the values of the progeny boars and barrows were equally high. The growth rate of the sires was significantly correlated with the growth rate of the progeny boars.

The animals were ranked and divided into three groups, the sires on the basis of their average fat measurements, and the boars and barrows from their progeny on the basis of the results of the lean cuts analysis of the carcasses. In the best and poorest groups distinguished by these different methods of evaluation, $40-80 \%$ of the sires were the same. The correspondence in the middle groups and in groupings made according to growth rate was smaller than in the groups mentioned above.
\end{abstract}

\section{Introduction}

Phenotype testing has recently come into general use in the selection of boars for breeding, and has often been combined with sib or progeny evaluation comprising barrows and/or females, i.e. animals with different sexual characteristics. Barrows, in particular, differ considerably from the other animals, since the castration of boars causes changes in the metabolism, affecting the rate of growth, feed efficiency, formation of fat and the amount of lean (Sharp et al. 1975). PERÄLÄ et al. (1974) and VARo (1975) also report that the extent of the differences between the sexes in the progeny varies from one boar to another. The question thus arises whether the results are equally reliable if different sexes are used in investigations of the genetic value of an animal. On the other hand, it is also questionable whether the selection of breeding boars based on phenotype testing alone is a sufficiently effective

1) Present address: Agricultural Research Centre, Department of Animal Husbandry, Tikkurila, Finland.

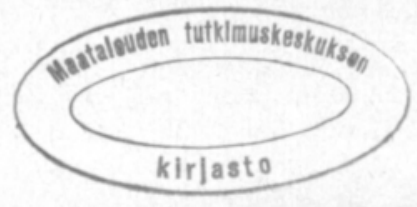


means of improving the carcass quality of animals raised for pork production, especially barrows.

An answer to these questions was sought in the present study, in which comparisons were made between the results of phenotype tests of boars and the results of progeny evaluations of both boars and barrows sired by them. Females were not included in the study.

\section{Material and methods}

The test animals were 15 phenotype-tested boars (8 Yorkshire and 7 Landrace), and 120 boars $(60 \mathrm{Y}+60 \mathrm{~L})$ and 120 barrows $(60 \mathrm{Y}+60 \mathrm{~L})$ chosen from their progeny. The investigation was conducted at an experimental station. The numbers of litters sired by the 15 boars ranged from 5 to 11 (average 8) (Table 1), and one boar and one barrow were taken from each of them for the progeny evaluations.

The characters determined in the phenotype evaluation of the boars were rate of growth, feed efficiency, thickness of fat and length of side. Fat thickness was measured ultrasonically with a Krautkrämer USM 1 or USK 5 SF, at the withers (1), midback (2), loin (3) and both sides (4 and 5) (Fig. 1), The length of the side was measured from the rear edge of the front leg to the base of the tail (Fig. 1). The measurements of the fat and the length of the side

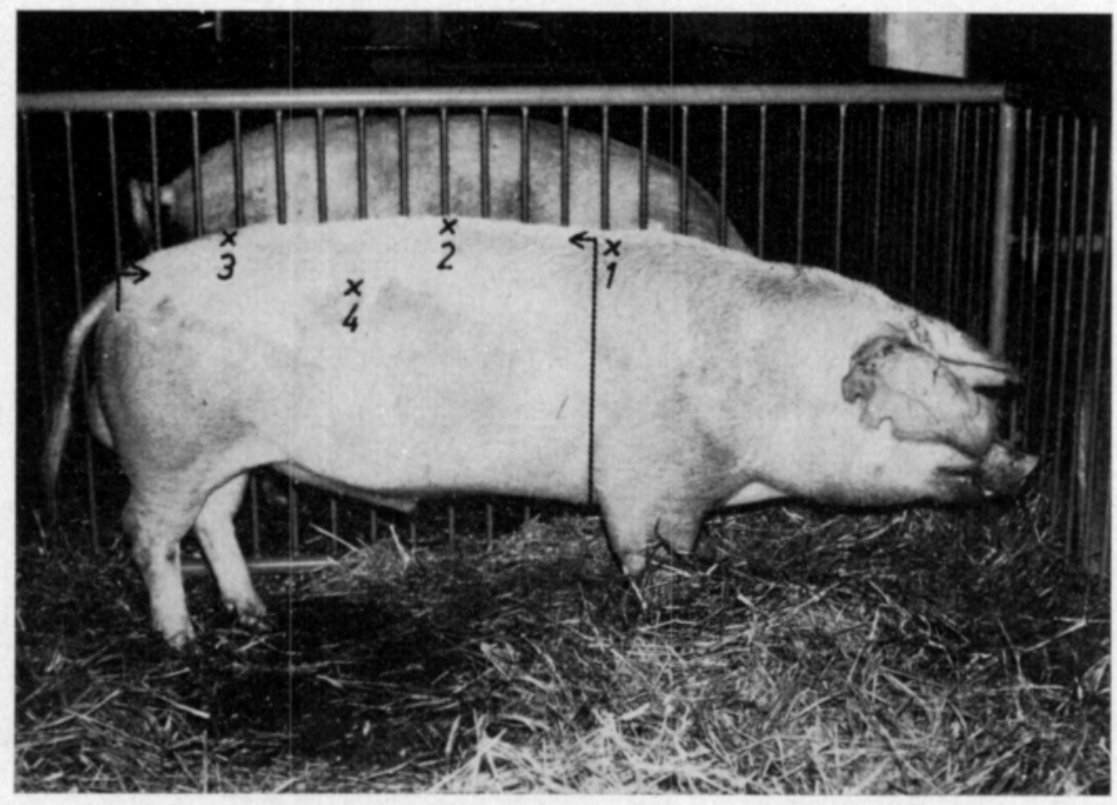

Fig. 1. Locations of ultrasonic measurements of fat on test boars, and manner in which length of side was measured.

$1=$ withers, behind shoulder blades

$2=$ midback, thinnest place

$3=$ loin, thinnest place

$4=$ sol. fat, right side, at rear edge of last rib, about $8 \mathrm{~cm}$ from midline of back (on pig weighing about $88 \mathrm{~kg}$ ).

Side length is the distance between the vertical lines. 
were made as near as possible to the time when the liveweight was $88 \mathrm{~kg}$, and, as they could not always be made sufficiently close to that date, the fat measurements were interpolated to the desired weight. The rate of growth and feed efficiency values were calculated for the weight range of $20-88 \mathrm{~kg}$. The boars were fed individually according to restricted energy norms $(0.9-3.0$ f.u./animal per day) (EtTala 1973 p. 39), because it was feared that abundant feeding might cause an increase in leg weaknesses.

The progeny were housed four to a pen and were group fed, the level of feeding approximating to appetite (1.2-3.2 f.u./animal per day) (ETTALA 1973, p. 45). Each pen contained pigs from two litters of the same boar. The rate of growth and average feed efficiency of the progeny were determined, and their carcass characteristics were evaluated by measurements made on the carcass section (Fig. 2) and lean cuts analysis (Fig. 3). In the lean cuts analysis, the most valuable parts of the half carcass (ham, loin, back, foreback and shoulder) were divided into two parts, namely meat + bone and fat + skin. The animals were slaughtered when they were as near as possible to a liveweight of $88 \mathrm{~kg}$. As with the sires, the rate of growth was calculated for the weight range $\mathbf{2 0}-\mathbf{8 8} \mathrm{kg}$. As the boars and barrows were housed in the same pens, separate feed efficiency values could not be determined.

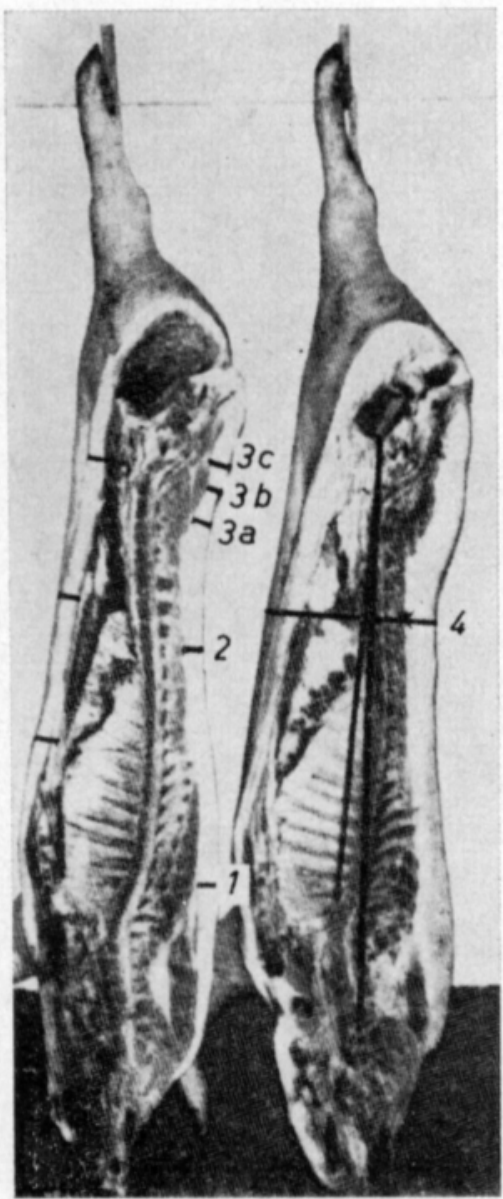

Fig. 2. Positions for fat thickness measurement of porcine carcass section (PARTANen 1965).

$1=$ withers, $2=$ midback, $3 \mathrm{a}=$ fore loin, $3 \mathrm{~b}=\mathrm{mid}$ loin (corresponding to loin fat measured ultrasonically), $3 \mathrm{c}=$ rear loin, $4=$ side fat.

The longissimus muscle is measured along the horizontal line shown, and the side length is the length of the short vertical line.

Fig. 3. Porcine carcass, showing the most important parts (UUSISALMI 1969). $1=$ ham, 2 = loin, $3=$ back, $4=$ foreback, $5=$ shoulder.

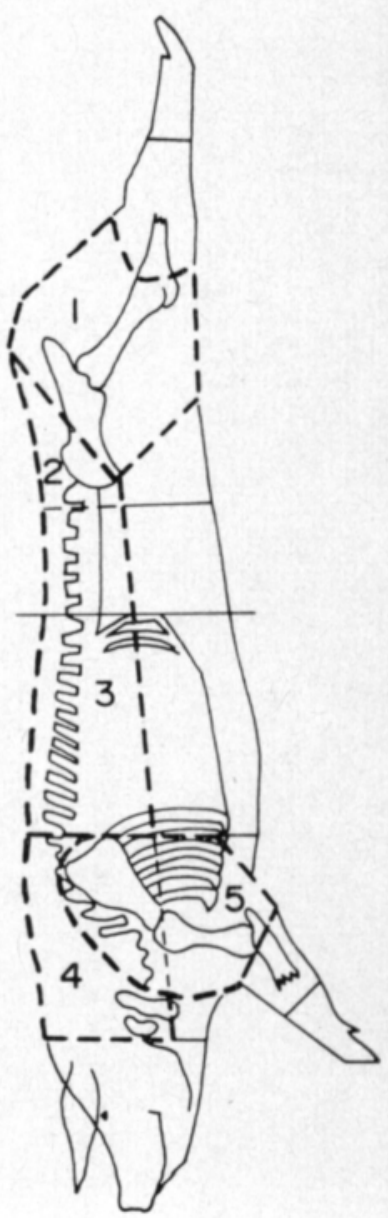




\section{Results and discussion}

Table 1 shows the results of the ultrasonic fat measurements of the sires and their ranking and division into three groups on the basis of the average fat thickness $\left(1,2,3, \frac{4+5}{2}\right)$. The aim in dividing the sires into groups was to discover whether the best third was sufficiently different from the other groups to justify selecting about $30 \%$ for breeding, or whether the poorest third, at least, could be distinguished from the others.

Groups I-III differed significantly $(\mathrm{P}<0.01)$ from each other in the average fat thickness $\left(1,2,3, \frac{4+5}{2}\right)$ and in the thickness of the back fat $(1,2,3)$. The poorest group also differed significantly from the others in the average thickness of the midback and the sides $(2,4,5)$. The individual fat measurements varied in many different ways in the different boars. Significant differences in the single measurements were mainly found between the two

Table 1. Ultrasonic fat measurements of sires, and their ranking and grouping according to mean fat thickness.

\begin{tabular}{|c|c|c|c|c|c|c|c|c|c|c|}
\hline \multirow{3}{*}{ Boars } & \multirow{3}{*}{ Breed $^{1}$ ) } & \multirow{3}{*}{$\begin{array}{l}\text { No. of } \\
\text { litters }\end{array}$} & \multicolumn{8}{|c|}{ Thickness of fat at $88 \mathrm{~kg}, \mathrm{~mm}$} \\
\hline & & & withers & midback & loin & sol.right & & Mean & & \\
\hline & & & (1) & (2) & (3) & (4) & $1,2,3$ & $\left.2,4,5^{2}\right)$ & $1,2,3$ & $\frac{4+5}{2}$ \\
\hline \multicolumn{11}{|l|}{ Group I } \\
\hline 1. Riku & L & 7 & 12.9 & 11.6 & 13.9 & 13.7 & 12.7 & 12.6 & 12.9 & \\
\hline 2. Ranu & $\mathbf{L}$ & 10 & 10.2 & 13.3 & 12.2 & 16.3 & 12.0 & 15.3 & 13.0 & \\
\hline 3. Rukki & L & 6 & 17.5 & 12.2 & 11.5 & 11.3 & 13.6 & 12.0 & 13.3 & \\
\hline 4. Nakeri & $\mathbf{L}$ & 11 & 19.0 & 12.7 & 12.0 & 11.9 & 14.6 & 12.1 & 13.9 & \\
\hline 5. Ripa & Y & 8 & 18.0 & 11.0 & 15.0 & 16.0 & 14.7 & 14.3 & 15.0 & \\
\hline Mean & & 8.4 & $15.5^{\mathrm{e}}$ & $12.2^{\mathrm{e}}$ & $12.9^{e}$ & $13.8^{\mathrm{ae}}$ & $13.5^{\mathrm{e}}$ & $13.3^{\mathrm{e}}$ & $13.6^{\mathrm{e}}$ & \\
\hline \multicolumn{11}{|l|}{ Group II } \\
\hline 6. Rape & $\mathbf{Y}$ & 8 & 20.9 & 12.0 & 15.9 & 14.9 & 16.2 & 13.2 & 15.7 & \\
\hline 7. Hymyri & $\mathbf{Y}$ & 9 & 20.5 & 14.6 & 17.5 & 16.6 & 17.6 & 15.9 & 15.9 & \\
\hline 8. Reka & $\mathbf{Y}$ & 5 & 19.1 & 14.0 & 16.1 & 18.1 & 16.4 & 16.4 & 16.4 & \\
\hline 9. Kilperi & $\mathrm{Y}$ & 10 & 20.0 & 13.1 & 17.0 & 18.1 & 16.8 & 16.1 & 16.9 & \\
\hline 10. Ruuppo & $\mathrm{Y}$ & 5 & 20.9 & 14.1 & 18.9 & 19.0 & 18.0 & 17.1 & 18.1 & \\
\hline Mean & & 7.4 & $20.3^{\text {ed }}$ & $13.6^{\mathrm{c}}$ & $17.1^{\mathrm{ad}}$ & $17.3^{b}$ & $17.0^{\text {de }}$ & $15.7^{e}$ & 16.9de & \\
\hline \multicolumn{11}{|l|}{ Group III } \\
\hline 11. Sapro & $\mathbf{L}$ & 8 & 22.8 & 16.7 & 17.8 & 18.7 & 19.0 & 18.0 & 19.0 & \\
\hline 12. Rata & $\mathbf{Y}$ & 9 & 22.4 & 15.5 & 20.4 & 18.5 & 19.5 & 17.5 & 19.2 & \\
\hline 13. Sapeli & L & 9 & 22.9 & 16.7 & 18.9 & 19.8 & 19.5 & 18.5 & 19.5 & \\
\hline 14. Rooli & L & 9 & 24.5 & 17.4 & 21.5 & 20.4 & 21.1 & 19.1 & 20.8 & \\
\hline 15. Riski & $\mathbf{Y}$ & 6 & 31.3 & 19.5 & 20.3 & 23.4 & 23.7 & 22.1 & 23.6 & \\
\hline Mean & & 8.2 & $24.8^{d}$ & $17.2^{\mathrm{d}}$ & $19.8^{\mathrm{bd}}$ & $20.2^{\text {bd }}$ & $20.6^{t}$ & $19.0^{d}$ & $20.4^{t}$ & \\
\hline
\end{tabular}

The significance of the differences between the group means was tested by the analysis of variance and Tukey's test (Steel and Torrie 1960).

1) $\mathrm{L}=$ Landrace, $\mathrm{Y}=$ Yorkshire. ${ }^{2}$ ) $5=$ sol. left.

$\mathrm{a}-\mathrm{b}: \mathrm{P}<0.05 ; \mathrm{c}-\mathrm{f}: \mathrm{P}<0.01$. 
Table 2. Growth rate and feed efficiency of boars and their ranking and grouping according to growth rate.

\begin{tabular}{|c|c|c|}
\hline & $\begin{array}{c}\text { Growth } \\
(20-88 \mathrm{~kg}) \\
\text { g/day }\end{array}$ & $\begin{array}{c}\text { f.u./kg wt. } \\
\text { increase } \\
(20-88 \mathrm{~kg})\end{array}$ \\
\hline \multicolumn{3}{|l|}{ Group I } \\
\hline 1. Hymyri ................... & 739 & 2.34 \\
\hline 2. Ruuppo ................ & 731 & 2.37 \\
\hline 3. Rata ..................... & 694 & 2.51 \\
\hline 4. Kilperi ..................... & 687 & 2.59 \\
\hline 5. Reka ....................... & 644 & 2.77 \\
\hline Mean ...................... & $699^{\circ}$ & $2.52^{\mathrm{e}}$ \\
\hline \multicolumn{3}{|l|}{ Group II } \\
\hline 6. Riski ...................... & 640 & 2.59 \\
\hline 7. Rooli ........................ & 624 & 2.73 \\
\hline 8. Rape .................... & 597 & 2.77 \\
\hline 9. Ranu ....................... & 591 & 3.01 \\
\hline 10. Rukki .................... & 580 & 3.17 \\
\hline Mean ...................... & $606^{d e}$ & $2.85^{\mathrm{c}}$ \\
\hline \multicolumn{3}{|l|}{ Group III } \\
\hline 11. Ripa .................... & 559 & 3.21 \\
\hline 12. Sapro .................... & 541 & 3.23 \\
\hline 13. Sapeli ....................... & 510 & 3.68 \\
\hline 14. Riku ...................... & 491 & 3.86 \\
\hline 15. Nakeri ................... & 436 & 4.05 \\
\hline Mean ...................... & $507 \mathrm{f}$ & $3.61^{\mathrm{d}}$ \\
\hline
\end{tabular}

Significance of differences tested as in Table 1.

extreme groups, though some also existed between adjacent groups (Table 1).

Table 2 shows the ranking of the sires according to the rate of growth. It differs markedly from the ranking on the thickness of the fat (Tables 1 and 2). In contrast, feed efficiency followed the ranking on growth rate fairly closely. All the groups differed significantly $(\mathrm{P}<0.01)$ from each other in respect of growth rate, and the poorest group differed significantly $(\mathrm{P}<0.01)$ from the others in respect of feed efficiency $(\mathrm{P}<0.01)$.

Table 3 gives the mean results of the progeny evaluations. Compared with the barrows, the boars grew significantly $(\mathrm{P}<0.01)$ more rapidly, were meatier $(\mathrm{P}<0.001)$, had less fat $(\mathrm{P}<0.001)$ and were also longer $(\mathrm{P}<0.001)$. The carcass score developed for selection was also higher $(\mathrm{P}<0.001)$ for the boars than for the barrows. The score takes into account the meatiness of the animal and the daily yield of meat, according to the following formula:

$$
\begin{aligned}
& \mathrm{Y}=\frac{\mathrm{A}}{\mathrm{B}} \times \frac{\mathrm{A}}{\mathrm{B}} \times 10, \\
& \text { where } \mathrm{Y}=\text { the score }
\end{aligned}
$$

$\mathrm{A}=$ weight in grams of the meat + bone of the most valuable parts of the half carcass.

$\mathrm{B}=$ age in days at slaughter minus half the age in days at a liveweight of $20 \mathrm{~kg}$.

$\mathrm{C}=$ weight of the half carcass in grams. 
Table 3. Mean values and standard deviations of characteristics of progeny (120 boars, 120 barrows).

\begin{tabular}{|c|c|c|c|c|c|}
\hline \multirow{2}{*}{ Characteristics } & \multicolumn{2}{|c|}{ Boars } & \multicolumn{2}{|c|}{ Barrows } & \multirow{2}{*}{$\frac{\text { Differences }}{\text { boars - barrows }}$} \\
\hline & mean & s.d. & mean & s.d. & \\
\hline 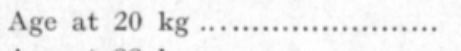 & 61.3 & 9.9 & 62.6 & 9.4 & -1.3 \\
\hline 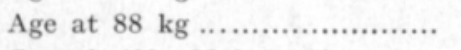 & 154.6 & 12.1 & 158.2 & 11.4 & $-3.6 * *$ \\
\hline Growth $(20-88 \mathrm{~kg}) \mathrm{g} /$ day $\ldots . .$. & 760.7 & 77.4 & 736.9 & 71.6 & $+23.8 * *$ \\
\hline $\begin{array}{l}\text { Carcass wt., kg ......................... } \\
\text { Fat thickness, mm }\end{array}$ & 67.8 & 2.3 & 67.1 & 2.1 & +0.7 \\
\hline withers ........................... & 33.7 & 3.8 & 38.1 & 4.0 & $-4.4 * * *$ \\
\hline midback ........................... & 16.8 & 3.1 & 21.3 & 3.3 & $-4.5 * * *$ \\
\hline loin (mean) ........................ & 21.3 & 4.0 & 26.7 & 3.9 & $-5.4 * * *$ \\
\hline side $\ldots \ldots \ldots \ldots \ldots \ldots \ldots \ldots \ldots \ldots \ldots \ldots \ldots \ldots \ldots \ldots \ldots$ & 20.7 & 4.0 & 25.5 & 4.4 & $-4.8 * * *$ \\
\hline Area of longissimus muscle, $\mathrm{cm}^{2}$ & 31.6 & 3.6 & 29.7 & 3.6 & $+1.9 * * *$ \\
\hline Side length, cm ...................... & 77.1 & 2.6 & 75.9 & 2.4 & $+1.2 * * *$ \\
\hline $\begin{array}{l}\text { Meat }+ \text { bone of half carcass, } g \\
\text { shoulder } \ldots \ldots \ldots \ldots \ldots \ldots \ldots \ldots \ldots \ldots\end{array}$ & 2925 & 245 & 2695 & 255 & $+230 * * *$ \\
\hline foreback .......................... & 2412 & 274 & 2257 & 280 & $+155 * * *$ \\
\hline 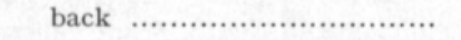 & 3896 & 376 & 3665 & 410 & $+231 * * *$ \\
\hline 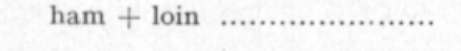 & 6093 & 468 & 5696 & 481 & $+397 * * *$ \\
\hline $\begin{array}{l}\text { Most valuable parts of } 1 / 2 \text { carcass, } \\
\text { meat }+ \text { bone, } g \ldots \ldots \ldots \ldots \ldots \ldots\end{array}$ & 15326 & 1077 & 14312 & 1127 & $+1014 * * *$ \\
\hline fat + skin, $g$. $\ldots \ldots \ldots \ldots \ldots \ldots \ldots$ & 4820 & 616 & 5670 & 694 & $-850 * * *$ \\
\hline fat : meat ....................... & 0.32 & 0.05 & 0.40 & 0.07 & $-0.8 * * *$ \\
\hline meat + bone, $\%$............... & 46.5 & 3.0 & 43.8 & 2.7 & $+2.7 * * *$ \\
\hline fat + skin, $\%$.................. & 14.6 & 1.9 & 17.4 & 2.0 & $-2.8 * * *$ \\
\hline 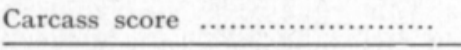 & 580.4 & 81.4 & 498.9 & 74.6 & $+81.5 * * *$ \\
\hline
\end{tabular}

The significance of differences between the means of the boars and barrows was tested by the least-squares analysis of variance (HARveY 1966). The variation due to differences in carcass weight and breed was eliminated by taking the former as a regression variable and the latter as a factor.

The differences in carcass quality observed between the boars and the barrows corresponded to those reported in other studies (CHARETTE 1961, Prescott and Lamming 1964, Schmid 1970, Staun 1965, Vold 1968). The greater length of the boars has also been observed in other investigations (Charette 1961, Prescott and Lamming 1964). On the other hand, reports vary regarding the growth rates of the boars and barrows. In some investigations, the boars grew more rapidly than the barrows, as they did here (Schmid 1970 , Staun 1965, Winters et al. 1942); in others the growth rates were the same (ChARETTE 1961), or the barrows grew more rapidly than the boars (Prescott and Lamming 1964, Winters et al. 1942). Prescott and Lamming (1964) attributed a decrease in the growth rate of the boars in the later stages of growth to an insufficiency of protein. In the present study, the restricted feeding norms limited the rate of growth of the sires; their mean rate was 604 $\mathrm{g}$ per day, whereas that of the boars sired by them was $761 \mathrm{~g}$. The restricted 
feeding norms may have affected the individuals with poor feeding efficiency more strongly than the others, selectively decreasing their rate of growth and fat thickness. This would partly explain the contradiction between the rankings made according to fat thickness and growth rate (Tables 1 and 2).

Phenotypic correlations between characteristics of the sires and characteristics of the boars and barrows in their progeny

Significant correlations existed between the ultrasonic fat measurements of the sires and the results of the lean cuts analysis made on the carcasses of the progeny $(\mathrm{P}<0.05-\mathrm{P}<0.001)$ (Table 4). The correlations of the sires with the barrows were a little higher than those with the boars, in respect of meatiness (meat + bone as \% of carcass), but generally a little lower in respect of the absolute values of the lean cuts analysis. However, the differences between the corresponding correlation coefficients did not prove significant when the $\chi^{2}$ test was applied. The correlations between the fat measurements

Table 4. Phenotypic correlations between ultrasonic fat measurements of sires and results of lean cuts analysis of the most valuable parts of the boar and barrow carcasses (sires 15, progeny $120+120)$.

\begin{tabular}{|c|c|c|c|c|c|c|c|}
\hline \multirow[b]{2}{*}{$\begin{array}{l}\text { Lean cuts analysis of } \\
\text { progeny carcasses }\end{array}$} & \multicolumn{7}{|c|}{ Fat thickness of sires, mm } \\
\hline & $\begin{array}{c}\text { withers } \\
\text { (1) }\end{array}$ & $\begin{array}{c}\text { midback } \\
\text { (2) }\end{array}$ & $\begin{array}{l}\text { loin } \\
(3)\end{array}$ & $\begin{array}{l}\text { sol. right } \\
\text { (4) }\end{array}$ & $1,2,3$ & $\begin{array}{l}\text { Mean } \\
2,4,5\end{array}$ & $1,2,3, \frac{4+5}{2}$ \\
\hline \multicolumn{8}{|l|}{ Meat + bone, $g$} \\
\hline 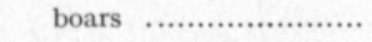 & -0.39 & -0.29 & -0.32 & -0.30 & -0.37 & -0.31 & -0.37 \\
\hline 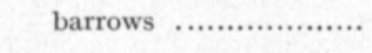 & -0.33 & -0.32 & -0.24 & -0.27 & -0.33 & -0.30 & -0.33 \\
\hline \multicolumn{8}{|l|}{ Fat + skin, $g$} \\
\hline boars ...................... & +0.25 & +0.28 & +0.21 & +0.18 & +0.26 & +0.20 & +0.25 \\
\hline 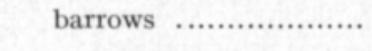 & +0.19 & +0.24 & +0.20 & +0.25 & +0.22 & +0.24 & +0.23 \\
\hline \multicolumn{8}{|l|}{ Fat : meat } \\
\hline boars ....................... & +0.35 & +0.34 & +0.30 & +0.27 & +0.36 & +0.28 & +0.34 \\
\hline 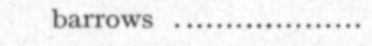 & +0.31 & +0.34 & +0.27 & +0.32 & +0.33 & +0.33 & +0.34 \\
\hline \multicolumn{8}{|l|}{ Meat + bone $\%$ of carcass } \\
\hline 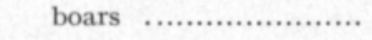 & -0.29 & -0.20 & -0.23 & -0.19 & -0.27 & -0.20 & -0.26 \\
\hline 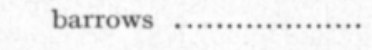 & -0.33 & -0.33 & -0.31 & -0.35 & -0.35 & -0.36 & -0.37 \\
\hline \multicolumn{8}{|l|}{ Fat + skin $\%$ of carcass } \\
\hline 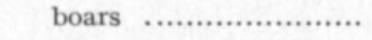 & +0.30 & +0.33 & +0.26 & +0.24 & +0.32 & +0.26 & +0.31 \\
\hline barrows . .................... & +0.26 & +0.31 & +0.22 & +0.27 & +0.28 & +0.28 & +0.28 \\
\hline \multicolumn{8}{|l|}{ Carcass score } \\
\hline boars ...................... & -0.28 & -0.26 & -0.23 & -0.20 & -0.28 & -0.22 & -0.27 \\
\hline barrows ................... & -0.26 & -0.35 & -0.23 & -0.30 & -0.30 & -0.33 & -0.31 \\
\hline
\end{tabular}

$\mathrm{P}<0.05, \mathrm{r} \leqq 0.19 ; \mathrm{P}<0.01, \mathrm{r} \leqq 0.25 ; \mathrm{P}<0.001, \mathrm{r} \leqq 0.32$ (d.f. 118 ).

The homogeneity of the pairs of correlations was tested with the $\chi^{2}$ test; there were no statistically significant differences. 
Table 5. Phenotypic correlations between mean ultrasonic fat measurements of sires and measurements made on boar and barrow carcasses, and also between lengths and growth rates of sires and progeny (sires 15 , progeny $120+120)$.

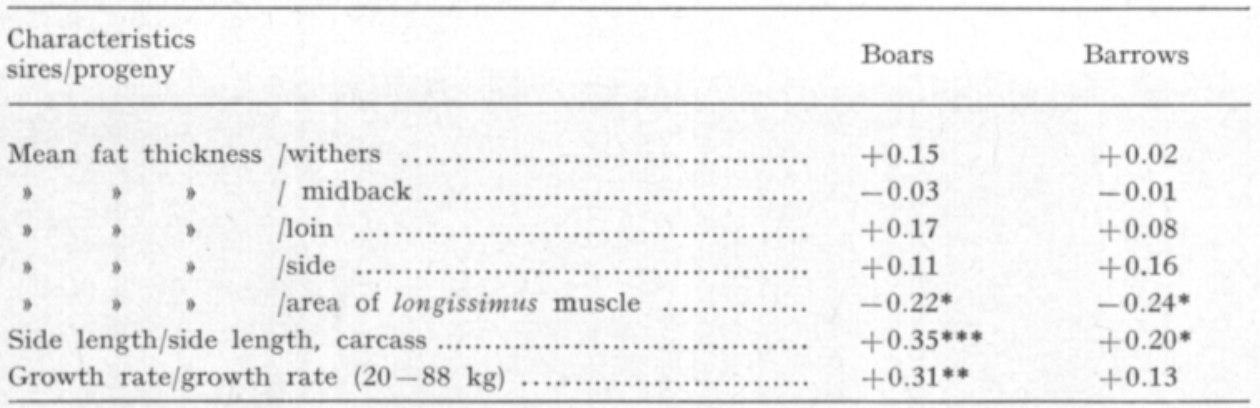

$* \mathrm{P}<0.05,{ }^{* *} \mathrm{P}<0.01,{ }^{* * *} \mathrm{P}<0.001$.

of the sires and the carcass scores of the progeny were also significant $(\mathrm{P}<0.05$ $-\mathrm{P}<0.001)$. The midback and side fat measurements of the sires showed slightly closer correlations with the carcass score of the barrows than with that of the boars, but, here again, the differences were not significant.

The measurements made on the carcass section showed much poorer correspondence with the characteristics of the sires than the results of the lean cuts analysis; the ultrasonic fat measurements of the sires correlated significantly $(\mathrm{P}<0.05)$ only with the cross-sectional area of the longissimus muscle (Table 5). The correlation between the side lengths of the sires and the boars was closer than that between the side lengths of the sires and the barrows $(\mathrm{P}<$ $0.001, \mathrm{P}<0.05)$. The rate of growth of the sires was significantly correlated only with that of the boars.

Ranking of sires according to their own phenotype evaluation compared with their rankings according to the evaluations of the boars and barrows in their progeny

Since the ranking of an animal determines whether it is selected for breeding, the ranking of the sires made on the basis of their own phenotype evaluation was compared with those made according to the evaluations of the boars and barrows in their progeny (Table 6). The values for the carcass and growth characteristics of the progeny were ranked from best to worst and divided into three groups. In all the groups, without exception, the boars had more lean meat and less fat than the barrows, and, with the exception of the weakest group, the boars also grew more rapidly than the barrows.

From the point of view of breeding, it would be most desirable for the best group to contain the same sires, whether the ranking was made according to their own phenotype or according to the evaluations of the boars or barrows in their progeny. It may be seen in Table 6 that when the criterion chosen was the absolute amount of meat + bone or fat + skin, or the fat + skin $\%$ of the carcass, $80 \%$ of the best sires were the same (4 out of 5 ) in rankings made according to the evaluations of the boars and barrows. Similarly, $80 \%$ were same when the ranking was made on their own phenotype, except in the 
case of the amount of meat + bone of the barrows, where only $60 \%$ were the same ( 3 out of 5 ). When the criterion of evaluation was the percentage of meat + bone, the fat-to-meat ratio or the carcass score, $60 \%$ correspondence was obtained between the rankings made on the evaluations of the boars and barrows, and the correspondence between the rankings according to the phenotypes of the sires and the evaluations of their progeny ranged from 40 to $80 \%$. Selection based on the rate of growth of the boars and barrows gave $60 \%$ correspondence between the best groups, but the correspondence between these groups and that obtained on the basis of the growth rate of the sires was only $20-60 \%$.

In the poorest group, selection according to the carcass scores of the boars and barrows gave exactly the same result, and gave $60 \%$ correspondence with selection based on the evaluation of the sires themselves (Table 6). When the criterion chosen was the absolute or percentage value of meat + bone, or the rate of growth, $80 \%$ correspondence was obtained between the boars and barrows and $40-60 \%$ between the sires and their progeny. With the other criteria, the correspondence was $60 \%$.

The correspondence between the results obtained with the different bases of selection was generally poorer in the middle group than in the two extreme groups, since shifts of the sires occurred in both directions (Table 6). For example, sires 10 and 12 were promoted to the best group when selection was based on the progeny, since the progeny of the former were meatier and those of the latter had less fat than could be expected from the fat measurements of the sires themselves. The animals most often demoted to the poorest group were sires 7 and 8 . It may be noted that there were only five litters for sires 10 and 8 (the one male left uncastrated died in each of the other five litters), so that the basis of the progeny evaluation was somewhat poorer for them than for the others, and this may have affected the results. The restricted rations fed to the sires may also have affected the results by preventing the full realization of their potentialities. This factor presumably exerted the strongest effect on the correspondence between the growth rates of the sires and their progeny.

In this study, fairly good correspondence was obtained between the results of phenotypic evaluation of boars and evaluations of boars and barrows in their progeny. Correspondence was best when the evaluations of the best and weakest individuals were compared with the carcass characteristics of their progeny. The results suggest that barrows can suitably be used in sibling and progeny evaluations. In the studies of Etrala (1973) and Schmid (1970) the lean cuts results of barrow sibs explained a significant, though not particularly large, proportion of the variation in carcass value of phenotypically tested boars. The contribution of the results of the barrow sibs was valuable since it explained the variation in the data on the meatiness, or meat percentage, of the boars best. The correspondence between the growth rates of the sires and the barrow progeny was poorer in this study than that of the carcass characteristics; Sснмг (1970) obtained a corresponding result in his sib evaluation. 


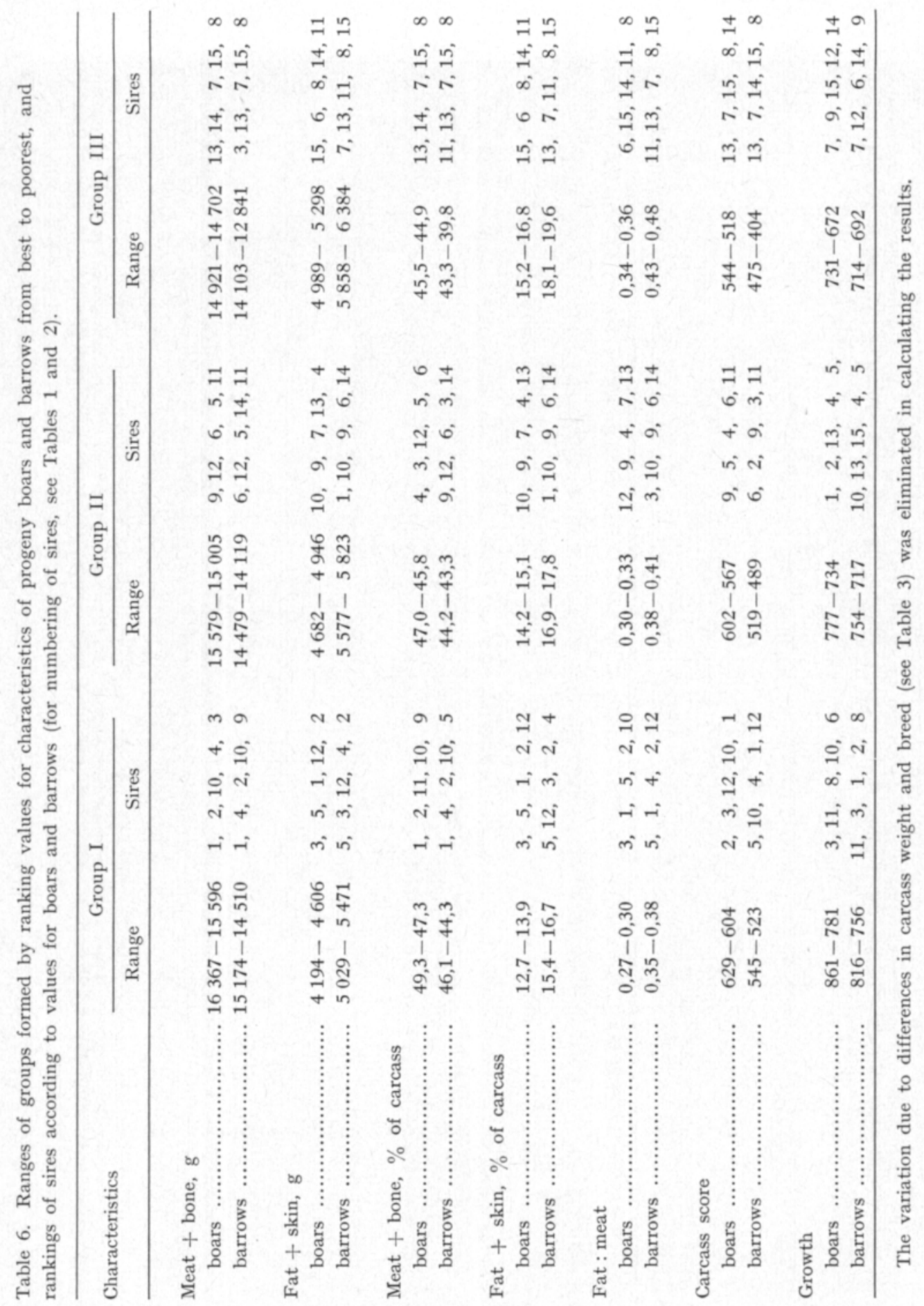




\section{REFERENCES}

Charette, L. A. 1961. The effects of sex and age of male at castration on growth and carcass quality of Yorkshire swine. Can. J. Anim. Sci. 41: 30-39.

EtralA, E. 1973. Boars for breeding: A study of methods of evaluation used at testing stations. J. Scient. Agric. Soc. Finl. 45:17-119.

HARVEY, W. R. 1966. Least-squares analysis of data with unequal subclass numbers. ARS 20-8. Agric. Res. Service, U. S. Dept. of Agric. 157 p.

PARTANen, J. 1965. Sikakantakokeiden tulokset vuodelta 1964. Summary: Results of pig progeny testing in the year 1964. Sika, 181: 25-51.

Perälä, M., Varo, M., Partanen, J. \& Alaviuhkola, T. 1974. Die Zuverlässigkeit der Nachkommenbewertung von Schweinen bei Anwendung eines Prüfverfahrens mit vorbestimmter Zeitdauer. Scient. - Techn. Conf. on Breed. Eval. of Bulls and Boars, Cracow, 3.-5. October 1974.

Prescott, J. H. D. \& Lamming, G. E. 1964. The effects of castration on meat production in cattle, sheep and pigs. J. Agric. Sci. 63: 341-357.

Scнмid, P. 1970. Ein Beitrag zur Eigen- und Geschwisterleistungsprüfung beim Schwein. Diss. 106 p. Zürich.

Sharp, R. N., Noland, P. R. \& Johnson, J. B. 1975. Relationships between performance traits and certain biological properties of testicular tissue in swine. J. Anim. Sci. 41: $87-93$.

Staun, H. 1965. Partiel kastration af ornegrise. Landøkonomisk Forsøgslaboratoriums efterårsmøde 1965: $67-71$.

Steel, R. G. D. \& Torrie, J. H. 1960. Principles and procedures of statistics. 481 p. New York.

Uusısalmi, U. 1969. Vorläufige Ergebnisse über das Messen der Schlachteigenschaften beim Schwein. J. Agric. Sci. 41: 50-59.

VAro, M., Perälä, M., Ojala, M. \& Varo, H. 1975. Experiences in the evaluation of carcass value of live pigs by ultrasonic photography. J. Scient. Agric. Soc. Finl. 47: 517-532.

VoLD, E. 1968. Kjött-feitt forholdet i slakt av råne og kastrat. Husdyrforsøksmøtet på Norges Landbrukshogskøle 5-6.12.1968. p. 182-185.

Winters, L. M., Сomstock, R. E. ,Jordan, D. F. \& Kiser, O. M. 1942. The effect of sex on the development of the pig. I. Differences in growth between boars and barrows by lines of breeding. J. Anim. Sci. 1: 41-47.

MS received December 5, 1975. 


\title{
Karjujen fenotyyppitestauksen sekä karjuilla ja leikoilla suoritetun jälkeläisarvostelun vastaavuudesta
}

\author{
Elsi EtTala \\ Helsingin yliopisto, Kotieläinten jalostustieteen laitos ${ }^{1}$ )
}

Tutkimuksessa on ollut 15 koeasemalla testattua karjua, jotka on jälkeläisarvosteltu 120 karju- ja 120 leikkojälkeläisen avulla, yksi karju- ja leikkoporsas kustakin pahnueesta. Karjujälkeläiset ovat olleet nopeakasvuisempia $(\mathrm{P}<0.01)$, lihakkaampia $(\mathrm{P}<0.001)$, vähemmän silavapitoisia $(\mathrm{P}<0.001)$ sekä pitempiä $(\mathrm{P}<0.001)$ kuin leikot.

Isien silavaluotaustulosten sekä karju- ja leikkojälkeläisten ruhon arvokkaimpien osien paloittelutulosten välillä on ollut merkitsevät fenotyyppiset korrelaatiot $(\mathrm{P}<0.05-\mathrm{P}<$ 0.001). Vastaavat korrelaatiot ovat karju- ja leikkojälkeläisillä olleet samanarvoisia. Isien kasvunopeus on korreloitunut merkitsevästi vain karjujälkeläisten kasvunopeuden kanssa.

Kun isät on asetettu keskimääräisen silavanpaksuuden ja karju- ja leikkojälkeläiset ruhon paloittelutulosten perusteella paremmuusjärjestykseen ja jaettu kolmeen ryhmäån, on parhaaseen ja heikoimpaan ryhmään saatu kullakin arvostelutavalla $40-80 \%$ :sesti samat isäkarjut. Keskimmäisessä ryhmässä samoin kuin kasvunopeuden mukaisessa ryhmittelyssä on vastaavuus ollut edellämainittuja pienempi.

1) Nykyinen osoite: Maatalouden tutkimuskeskus, Kotieläinhoidon tutkimuslaitos, Tikkurila. 